\title{
認知症との共生の鍵となる取り組みの最前線
}

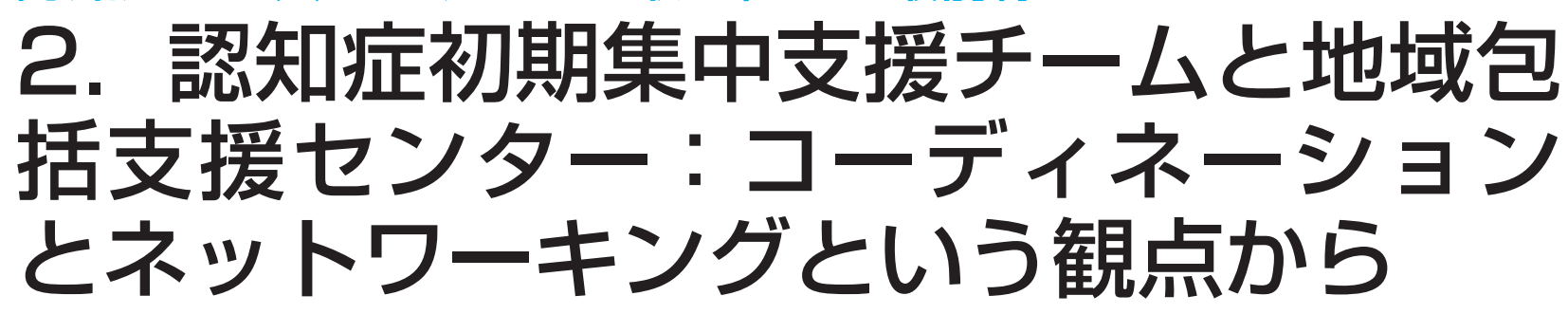

Initial-phase intensive support team and community general support center:

From the perspective of coordination and networking of social support

\section{粟田 主一}

\section{要 約}

社会支援のコーディネーションとネットワーキングは, 「認知症とともに暮らせる社会」を実現するための 鍵概念である. 認知症初期集中支援チームや地域包括支援センターの本来業務はコーディネーションとネッ トワーキングに他ならない. 地域の特性に応じて, コーディネーションとネットワーキングのあり方を深化 させ, 現存する縦割りの事業を効果的に整理・統合していくことが, 地域共生社会の実現をめざすこれから のわれわれの課題である.

Key words 認知症初期集中支援チーム, 地域包括支援センター, コーディネーション, ネットワーキング, 地域共生社会

（日老医誌 $2020 ； 57 ： 22-27$ )

\section{はじめに}

認知症初期集中支援チームとは，認知症になっても 本人の意思が尊重され，できる限り住み慣れた地域の よい環境で暮らし続けることができるように，本人が 暮らす地域の中で, 認知症の初期支援を包括的・集中 的に行う多職種協働チームである ${ }^{122}$. 本稿では, 認知 症初期集中支援チームが制度化されるまでの経緯，今 日の活動状況，しばしば指摘される問題点を解説した 上で, 今後の方向性について私見を述べることとする.

\section{制度化されるまでの経緯}

2012 (平成 24）年 6 月に厚生労働省認知症施策検 討プロジェクトチームは，これまでの認知症施策を再 検証し，これからの認知症施策が目指すべき基本目標 を定めた「今後の認知症施策の方向性について」をと りまとめだ．そこでは,「認知症になっても本人の意 思が尊重され，できる限り住み慣れた地域のよい環境 で暮らし続けることができる社会」を実現するために， 「危機」が発生してからの「事後的な対応」ではなく, 「危機」の発生を防ぐ「早期・事前的な対応」の必要

東京都健康長寿医療センター研究所

連絡責任者：粟田主一 東京都健康長寿医療センター研究所〔テ173-0015 東京都板橋区栄町 35-2〕

e-mail: awata@tmig.or.jp

doi: 10.3143 /geriatrics.57.22 
表 1 認知症施策推進大綱が掲げる認知症初期集中支援チームの目標

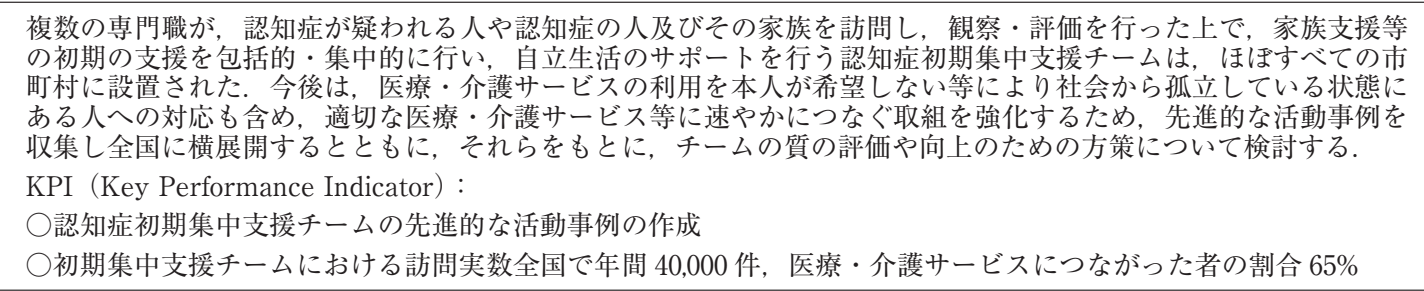

性が強調された。そのような文脈で提案された事業が 認知症初期集中支援チームである。

その後,この提案に基づき，2012（平成 24）年度 に，宮城県仙台市，東京都世田谷区，福井県敦賀市の 3 自治体において事業化のためのパイロット研究が行 われた。また，2013（平成 25）年度には，全国 14 市 町村において「認知症初期集中支援チーム設置促進モ デル事業」が実施され，2014（平成 26）年度には, 地域支援事業の任意事業として，全国 41 市町村にお いて「認知症初期集中支援推進事業」が実施された。 これらの結果を踏まえ，2015（平成 27）年度に，地 域支援事業における認知症総合支援事業（介護保険法 第 115 条の 45 第 2 項第 6 号）の一事業として「認知 症初期集中支援推進事業」が制度化された。尚，2015 (平成 27）年 1 月に政府が示した「認知症施策推進総 合戦略（新オレンジプラン）」吕では，2018（平成 30） 年度までに全国のすべての市町村で事業化する目標が 設定され，現在その目標はほぼ達成されている。そし て，2019 年 6 月に閣議決定された認知症施策推進大 綱5)では，表 1 に示すような新たな目標が掲げられて いる.

\section{今日の活動状況}

認知症初期集中支援チームの活動状況については, 2015 (平成 27）年度以降，国立長寿医療研究センター が経年調査を実施している。2018（平成 30）年度の 調査 ${ }^{6}$ に協力が得られた全国 2,390チームの活動状況 を概観すると，チームが設置されている機関は地域包 括支援センターが最も多く，支援対象者の属性では女 性が多く，年齢階級では 80〜84 歳が多く，世帯状況 では独居が約 4 割を占め, 把握経路では家族が約 4 割
を占め，約 4 割が困難事例であることが明らかにされ ている（表 2)。また, 約 6 割が要介護認定未申請者, 約 7 割が認知症高齢者の日常生活自立度 I II の軽度 例, 約 6 割が未診断例であった（表 3 )。支援の実施 状況では，支援対象者 1 人あたりの訪問回数(中央值) は 3 回, 1 回の訪問支援に要する時間（中央值）は 60 分であり，初回訪問を担当する専門職は看護師が最も 多く，対象者を把握してから初回訪問までの日数（中 央值）は 8 日，支援期間（中央值）は 57 日と報告さ れている（表 4)，終了時の状況については，支援開 始時に未診断であった事例のうち約 6 割が認知症の診 断, 約 1 割が認知症以外の診断に至り，支援開始時に 介護サービスが利用されていなかった事例のうち $54 \%$ が介護保険サービス，6\% が介護保険外サービス の利用につながり，74\%が在宅生活を継続していた （表 5)。支援前後の評価尺度の比較では，認知機能障 害・生活障害の程度（DASC-21）には変化が認めら れなかったが, 認知症の行動・心理症状（DBD-15）, 家族の介護負担度（J-ZBI_8）に改善が認められた。

\section{しばしば指摘される問題点}

認知症初期集中支援推進事業については，以下のよ うな問題がしばしば指摘されている.

\section{1. 支援対象者が把握されにくい}

認知症は, 通常, 本人または家族によって気づかれ, 本人・家族が医療機関や地域包括支援センターにアク セスし, そこから診断やサービスにつながる.しかし， 本人や周囲の知識が不十分であったり，社会的孤立に よって情報が不足していたり，認知症に対する差別や 偏見を背景にして「診断されること」「支援されること」 
表 2 認知症初期集中支援チームの活 動状況

\begin{tabular}{|c|c|}
\hline \multicolumn{2}{|l|}{ チームの設置場所 $(n=2,390)$} \\
\hline \multicolumn{2}{|l|}{ 地域包括支援センター } \\
\hline 行政機関 & $12.1 \%$ \\
\hline 医療機関（病院・診療所） & $10.2 \%$ \\
\hline 認知症疾患医療センター & $4.1 \%$ \\
\hline 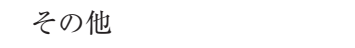 & $29.0 \%$ \\
\hline 不明 & $11.7 \%$ \\
\hline \multicolumn{2}{|l|}{ 性別（n=2,390） } \\
\hline 男性 & $37.0 \%$ \\
\hline 女性 & $63.0 \%$ \\
\hline \multicolumn{2}{|l|}{ 年齢（n=2,390） } \\
\hline 64 歳以下 & $1.3 \%$ \\
\hline $65 \sim 69$ & $4.9 \%$ \\
\hline $70 \sim 74$ & $10.3 \%$ \\
\hline $75 \sim 79$ & $22.5 \%$ \\
\hline $80 \sim 84$ & $31.8 \%$ \\
\hline 85 歳以上 & $29.0 \%$ \\
\hline \multicolumn{2}{|l|}{ 世帯状況（n=2,390） } \\
\hline 独居 & $37.9 \%$ \\
\hline 夫婦のみ & $29.0 \%$ \\
\hline その他 & $32.9 \%$ \\
\hline \multicolumn{2}{|l|}{ 把握経路（n=2,390） } \\
\hline 家族 & $40.8 \%$ \\
\hline ケアマネジャー & $9.2 \%$ \\
\hline 医療機関 & $6.4 \%$ \\
\hline 民生委員 & $5.3 \%$ \\
\hline 近隣住民 & $4.4 \%$ \\
\hline 本人 & $2.2 \%$ \\
\hline その他 & $31.5 \%$ \\
\hline \multicolumn{2}{|l|}{ 困難事例（n=2,390） } \\
\hline 該当 & $39.7 \%$ \\
\hline \multicolumn{2}{|c|}{$\begin{array}{l}\text { 平成 } 30 \text { 年度老人保健健康増進等事業報告 } \\
\text { 書「認知症初期集中支援チームのの設置後 } \\
\text { の効果に関するる研究」（国立長寿医療研究 } \\
\text { センター）より作成. 調査に協力が得ら } \\
\text { れた全国 } 2,390 \text { チームのデータに基づく. }\end{array}$} \\
\hline
\end{tabular}

を忌避する傾向があれば，支援対象者として把握され にくいであろう。これに加えて医療機関や地域包括支 援センターの職員自身に認知症に気づき，ニーズを感 知する能力が不足していれば，支援対象者の把握はさ らに困難になるであろう。活動状況調査によれば支援 対象者の約 4 割が独居である.このことは, 情報やサー ビスへのアクセシビリティを高める環境整備が, 認知 症施策の基本的課題の一つであることを示唆してい る.
表 3 認知症初期集中支援チームの活動状況

(2) 支援対象者の概要一その 2

\begin{tabular}{|c|c|}
\hline \multicolumn{2}{|c|}{ 要介護認定 $(n=2,390)$} \\
\hline 非該当 & $5.1 \%$ \\
\hline 要支援 1 & $4.0 \%$ \\
\hline 要支援 2 & $12.9 \%$ \\
\hline 要介護 1 & $4.8 \%$ \\
\hline 要介護 2 & $1.8 \%$ \\
\hline 要介護 3 & $0.5 \%$ \\
\hline 要介護 4 & $0.2 \%$ \\
\hline 要介護 5 & $1.5 \%$ \\
\hline 申請中 & $8.2 \%$ \\
\hline 申請なし & $58.6 \%$ \\
\hline 不明 & $2.3 \%$ \\
\hline \multicolumn{2}{|c|}{ 認知症高齢者の日常生活自立度 $(\mathrm{n}=2,390)$} \\
\hline I & $17.3 \%$ \\
\hline IIa & $25.0 \%$ \\
\hline $\mathrm{IIb}$ & $30.3 \%$ \\
\hline IIIa & $10.4 \%$ \\
\hline IIIb & $2.9 \%$ \\
\hline IV & $1.5 \%$ \\
\hline M & $1.1 \%$ \\
\hline 不明 & $11.6 \%$ \\
\hline \multicolumn{2}{|c|}{ 医療機関への通院状況 $(n=2,390)$} \\
\hline あり & $61.9 \%$ \\
\hline なし & $37.5 \%$ \\
\hline 不明 & $0.7 \%$ \\
\hline \multicolumn{2}{|c|}{ 認知症の診断（n=2,390） } \\
\hline あり & $32.3 \%$ \\
\hline なし & $58.3 \%$ \\
\hline 不明 & $9.4 \%$ \\
\hline \multicolumn{2}{|c|}{ 介護サービスの利用 $(\mathrm{n}=2,390)$} \\
\hline 利用あり & $11.5 \%$ \\
\hline かつ利用あり & $3.6 \%$ \\
\hline 利用なし & $78.0 \%$ \\
\hline 不明 & $2.7 \%$ \\
\hline \multicolumn{2}{|c|}{$\begin{array}{l}\text { 平成 } 30 \text { 年度老人保健健康増進等事業報告書「認知症 } \\
\text { 初期集中支援チームの設置後の効果に関する研究」(国 } \\
\text { 立長寿医療研究センター) より作成. 調査に協力が得 }\end{array}$} \\
\hline
\end{tabular}

\section{2. 地域包括支援センターの通常業務とのす み分け難} しい

地域包括支援センターは，地域包括ケアシステムを 実現するための実践的調整機関である。その方法論は 「多職種協働による社会支援の統合的調整」によって 基礎づけられるものであるが，それは認知症初期集中 支援チームの方法論と一致する。しかし，認知症とと もに生きる本人の地域生活の継続を実現するための社 
表 4 認知症初期集中支援チームの活動状況

（3）支援の実施状沉

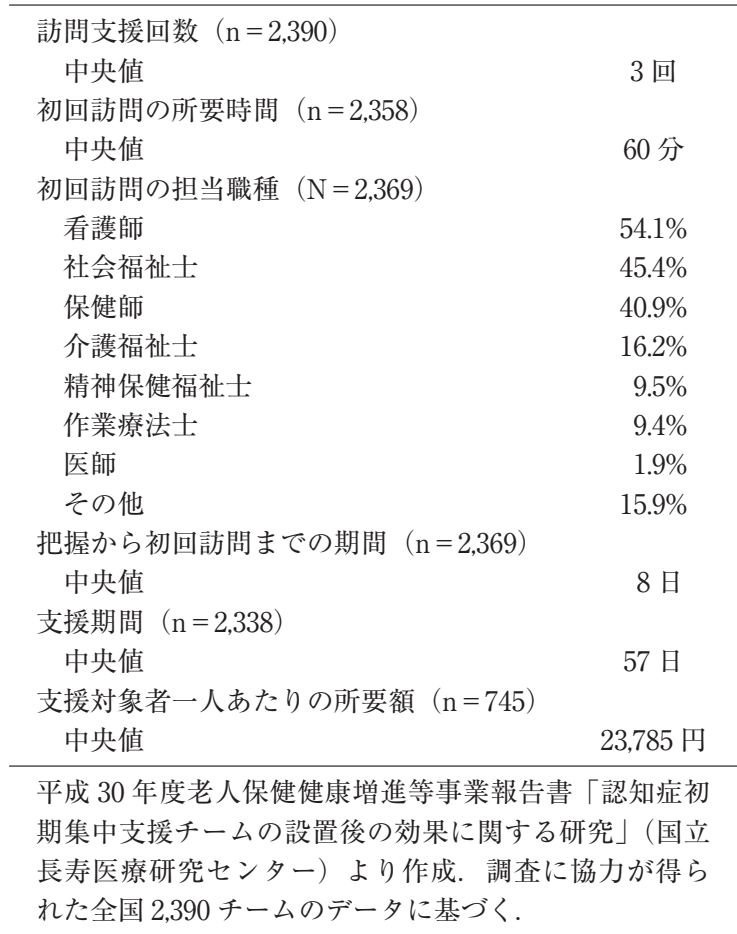

会支援の統合的調整には，相応の技能や体制を必要と する．筆者の理解では，2012 年当時のわが国の地域 包括支援センターには，そのような技能と体制は確保 されていなかった？そのために認知症初期集中支援 チームが必要とされたのであろう。このような観点に 立つと, 認知症初期集中支援推進事業は, 今後, それ ぞれの地域の特性に応じて, 市町村の責務において, 地域包括支援センターの本来業務（包括的支援事業） との効果的な連携・整理・統合が必要になるであろ う.

\section{3. 認知症の初期支援というよりも，困難事例への対 応が求められている}

活動状沉調查によれば，支援対象者の約 4 割が困難 事例である。この結果に対して,「認知症初期集中支援 チームの目的は認知症の初期支援にあるのだから，事 業の目的に反する」という批判もある。しかし，地域 には，複雑な生活課題に直面し，困難な状況に抢かれ ている認知症の本人・家族が数多く扔り, 従来の政策 ではそのような事態に適切に対処できなかったため
表 5 認知症初期集中支援チームの活 動状況

（4）支援終了時の状況

\begin{tabular}{lr}
\hline 診断の導入 $(\mathrm{n}=1,542)$ & \\
認知症の診断に至った & $58.5 \%$ \\
認知症以外の診断に至った & $12.3 \%$ \\
診断に至っていない & $26.5 \%$ \\
不明 & $2.7 \%$ \\
介護サービスの導入 $(\mathrm{n}=1,949)$ & \\
介護保険サービス & $53.9 \%$ \\
その他のサービス & $5.7 \%$ \\
上記の併用 & $1.5 \%$ \\
利用に至っていない & $31.1 \%$ \\
不明 & $7.8 \%$ \\
転帰 ( $\mathrm{n}=2,390)$ & \\
在宅継続 & $73.6 \%$ \\
入院 & $10.3 \%$ \\
入所・入居 & $7.6 \%$ \\
その他 & $0.5 \%$ \\
死亡 & $0.5 \%$ \\
不明 & $7.5 \%$ \\
\hline
\end{tabular}

平成 30 年度老人保健健康増進等事業報告 書「認知症初期集中支援チームの設置後 の効果に関する研究」(国立長寿医療研究 センター）より作成．調查に協力が得ら れた全国 2,390 チームのデー夕に基づく.

に，専門性の高い認知症初期集中支援チームに助けが 求められているのだという事実を看過してはならな い.

かつては，老人保健法や精神保健福祉法に定められ る老人保健相談事業や精神保健福祉相談事業が, 高齢 者の複雑困難事例に対応してきたという歴史があ $3^{7) \sim 9)}$. しかし， 2005 年の介護保険法改正以降，老人 保健法の廃止と地域包括支援センターの創設によっ て，地域包括支援センターがこうした事例に直面する ようになった，しかし，地域包括支援センターはそれ に対応できるようには設計されていない，複雑困難事 例に対応するには, 公的な責務として, 人権に配慮し, 専門性の高い多職種協働チームが包括的な支援を展開 する必要がある. 残念ながら, 今日の認知症初期集中 支援チームにもそのような機能は担保されていない. しかし，認知症とともに困難な状況に陥っている人々 が数多く暮らしているというわが国の現状を可視化さ せたという点において重要な意味をもつ.「事業の目的 


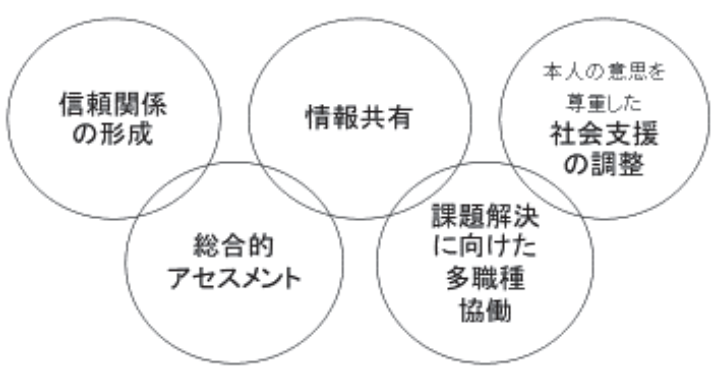

図1 コーディネーションのための 5 つのプロセス

に反する」という批判よりも, 認知症初期集中支援チー ムが直面している複雑困難事例に適切に対応するため の体制整備と, 複雑困難化の回避をめざした初期支援 の実践が必要であろう。

\section{今後の方向性について}

筆者らは,「本人の視点に立って必要な社会支援を統 合的に調整すること」をコーディネーション,「社会支 援の利用・提供を可能とする地域社会の構造をつくる こと」をネットワーキングと呼び, これらを「認知症 とともに暮らせる社会」を実現するための鍵概念とし て提唱している ${ }^{10111}$.

コーディネーションには，少なくとも図 1 に示す 5 つのプロセスの重層的・反復的な実践が必要である.

(1)信頼関倸の形成とは，本人との間で信頼できるパー トナーシップを築くことであり，それは意思決定支援 の前提である. (2)総合的アセスメントとは，認知症に 関する梁い理解を背景に, 本人の希望・生活課題・社 会支援ニーズを総合的に把握することである。（3)情報 共有とは，本人，家族，多職種間で情報を共有するこ とである. (4)課題解決に向けた多職種協働とは, 本人 の主体性を尊重しながら, 可能性のある課題解決に向 けて，本人とともに歩んでゆこうとするアプローチで ある. (5)本人の意思を尊重した社会支援の調整とは, 意思決定支援のプロセスを踏まえて，必要とされる社 会支援の利用と提供を調整することである。一方,ネッ トワーキングには，現存する医療・介護・居住支援・ 生活支援・家族支援・経済支援・権利擁護支援へのア クセシビリティの確保, “顔の見える”連携体制の構築,

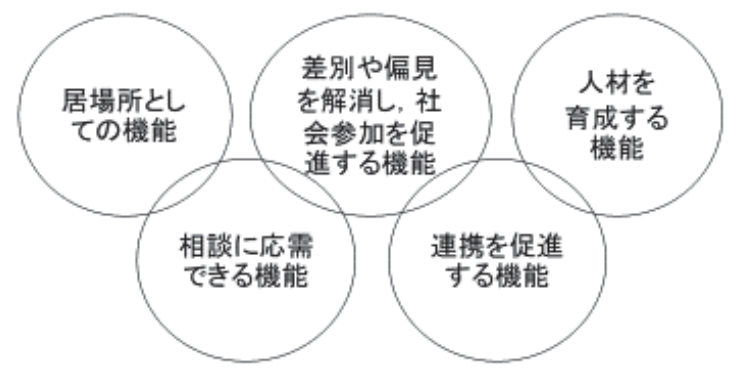

図 2 ネットワーキングの推進をめざす地域の拠点に 求められる機能

不足している資源の開発や新たなサービス（特に生活 支援に関するサービス）のイノベーションなどが含ま

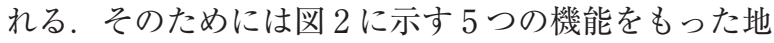
域の拠点をつくることが有効かと思われる ${ }^{11)}$.

高齢化や人口減少が進むわが国では，分野や世代を 超えて，人と人，人と資源とのつながりを保持し，尊 厳と希望をもって生きることができる地域共生社会の 創出が求められている ${ }^{12)}$. コーディネーションとネッ トワーキングはそのための方法論である。認知症初期 集中支援チームや地域包括支援センターの本来業務は コーディネーションとネットワーキングに他ならな い. 地域の特性に応じて，コーディネーションとネッ トワーキングのあり方を樑化させ，現存する縦割りの 事業を効果的に整理・統合していくことが，地域共生 社会の実現をめざすこれからのわれわれの課題であろ う.

著者の COI（Conflict of Interest）開示：本論文発表内 容に関連して特に申告なし

\section{文献}

1）粟田主一編著：認知症初期集中支援チーム実践テキス トブック，DASCによる認知症アセスメントと初期 支援，中央法規，東京， 2015 .

2）厚生労働省：地域支援事業実施要綱. https://www.m hlw.go.jp/content/12300000/000506705.pdf (accessed 2019-4-26).

3）厚生労働省認知症施策検討プロジェクトチーム：今後 の認知症施策の方向性について. https://www.mhlw. go.jp/stf/shingi/2r9852000002fv2e-att/2r9852000002f 
v5j.pdf (accessed 2012-6-18).

4) 厚生労働省：認知症施策推進総合戦略（新オレンジプ ラン). https://www.mhlw.go.jp/stf/seisakunitsuite/ bunya/0000064084.html (accessed 2015-1-15).

5) 認知症施策推進関係閣僚会議: 認知症施策推進大綱. https://www.mhlw.go.jp/content/12300000/00051943 4.pdf (accessed 2019-6-18).

6) 国立長寿医療研究センター：認知症初期集中支援チー ムの設置後の効果に関する研究事業（研究代表者：熟 見幸彦). 平成 30 年度老人保健事業推進費等補助金 (老 人保健健康増進等事業分）報告書. https://www.ncg g.go.jp/ncgg-kenkyu/documents/H30rouken-5houkok u.pdf

7）粟田主一：過疎高齢地域に在住する痴呆性老人早期診 断・早期対応システムの構築に関する実践的研究 (1). 保健所老人精神保健相談事業・地域総合病院連携シス テムの意義と課題. 老年精神医学雑誌 1999; 10: 339346.

8）粟田主一：過疎高齢地域に在住する痴呆性老人早期診 断・早期対応システムの構築に関する実践的研究 (2). 精神医学的相談と地域精神保健チームの連携を含む統
合的地域ケアシステム。老年精神医学雑誌 $2002 ; 13$ : $1175-1184$.

9）井藤佳恵，佐々木由香理，櫻井千絵ほか：地域におい て困難事例化する認知症高齢者が抱える困難事象の特 徵：認知症ステージによる検討. 老年精神医学雑誌 2013; 13: 1047-1061.

10）地方独立行政法人東京都健康長寿医療センター：認知 症とともに暮らせる社会に向けて、コーディネーショ ンとネットワーキングの手引き。東京都福祉保健局. http://www.fukushihoken.metro.tokyo.jp/zaishien/ni nchishou_navi/torikumi/jigyou/caremodel/pdf/tebik i.pdf

11）地方独立行政法人東京都健康長寿医療センター：認知 症とともに暮らせる社会に向けて。地域づくりの手引 き. 東京都福祉保健局. http://www.fukushihoken.m etro.tokyo.jp/zaishien/ninchishou_navi/torikumi/ma nual_text/pdf/besshil.pdf

12）厚生労働省：「地域共生社会」の実現に向けて. http s://www.mhlw.go.jp/stf/seisakunitsuite/bunya/0000 184346.html 